${ }^{7}$ Atlas of Sioux County, Iowa, Section II (Chicago, 1908), p. 6. 187.

${ }^{8}$ William H. Clark, Farms and Farmers (Boston, 1945), pp. 156-

${ }^{9}$ Some of the flavor of the threshing season was revealed in C. L. Miller, "Call of the Harvest," Colliers, L (October 5, 1912), p. 42.

${ }^{10}$ An analysis of rural social life around the turn of the century suggests that President Theodore Roosevelt's Report of the Country Life Commission failed in many ways to understand or discover the bonds of community which actually existed in rural America. See Report of the Country Life Commission (60 Congress, II Session, Senate Documents 705, Serial 5408, Washington, 1909).

${ }^{11}$ Alton Democrat (October 1, 1904).

\title{
Antique Car Donated To Museum
}

On Tuesday, May 16, 1972, the Department of History and Archives in Des Moines was given a nostalgic momento of Iowa's early motoring era. The Maytag Company of Newton, Iowa donated to the Museum a 1910 Maytag Pleasure car. The automobile is in excellent condition, has all of its working parts, and is now on display in the basement area of the museum.

A brief perusal of the history of the Maytag shows that it was manufactured in the years $1909-1910$ by the MaytagMason Motor Car Company-an offshoot of the Mason Motor Car Company of Waterloo. In 1909 F. L. Maytag decided to expand his interests and invested $\$ 300,000$ in Edward B. Mason's automobile Company. ${ }^{1}$ Mason needed the capital, and Maytag was interested in becoming a part of the exciting and expanding automobile manufacturing industry. Maytag gradually assumed control of the Company, and its name was then changed to Maytag-Mason Company.

The Maytag Pleasure car is an example of one of the first cars manufactured by the Company. It contains a twocylinder engine designed by Fred and August Duesenberg, and was acclaimed for its climbing power. The car was ad-

${ }^{1}$ George S. Mills, Rogues and Heroes from Iowa's Amazing Past (Ames: The Iowa State University Press, 1972), p. 18. 


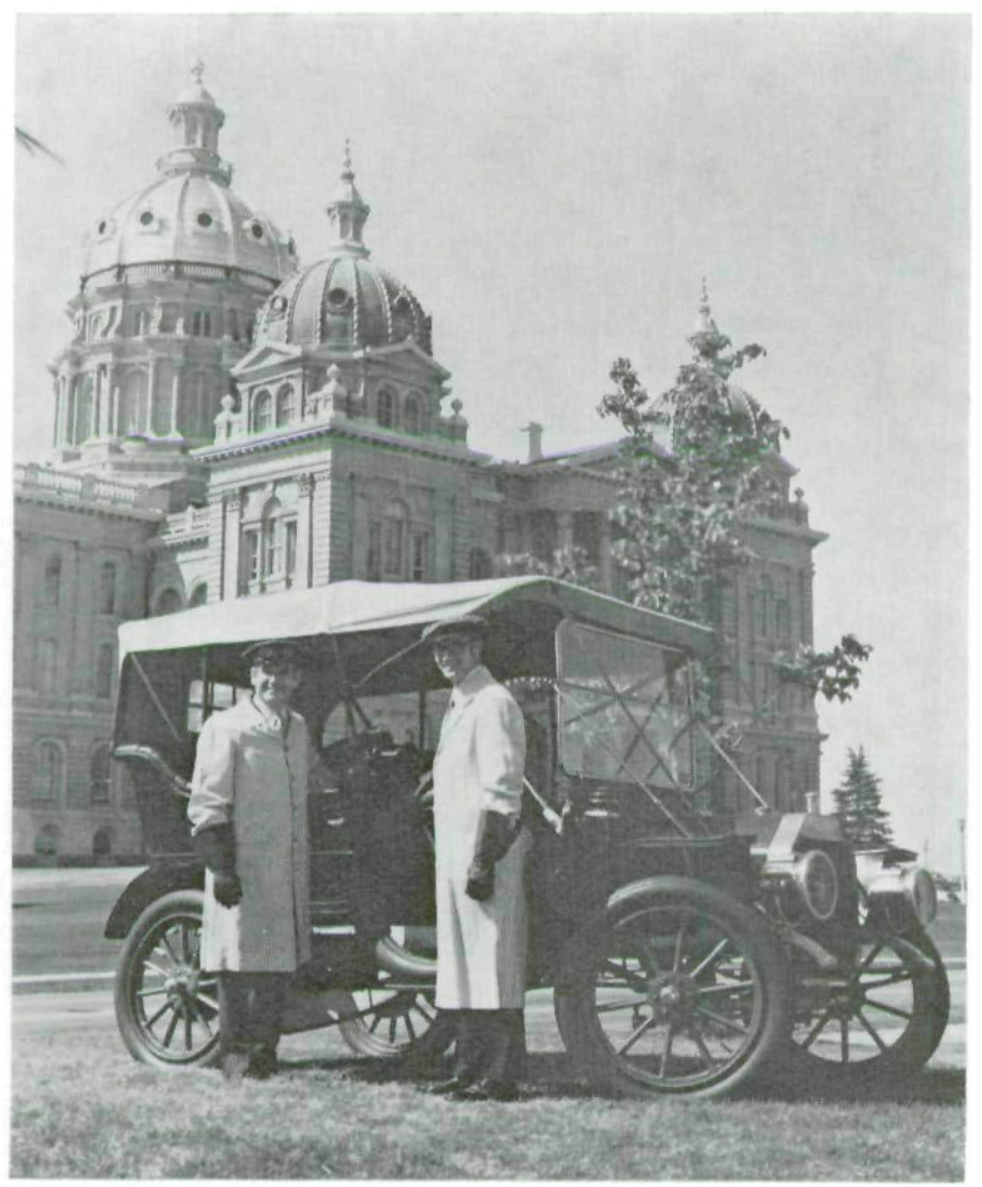

Photo by Public Relations Dept. Maytag Company

In a brief, informal ceremony on the front lawn of the Historical Building, the Maytag Company of Newton, lowa, officially presented to the State the title to the 1910 Pleasure car. Pictured above, in appropriate motoring attire for the era, are Governor Ray, who accepted the gift on behalf of the State, and Daniel J. Krumm, President of the Maytag Company. 
vertised as being able to ascend a 50 percent grade, and this fact was undeniably demonstrated one day when the car was driven all the way up the west steps of the Capitol.

According to an article which appeared in the November 11, 1951 issue of the Cedar Rapids Gazette, "Since the inception of the industry (automobile) in 1890, eight of the 1775 cars produced in the United States were made in Iowa." Although this estimate may be inaccurate, it is interesting to note the eight cars named in the article: the Adams Farwell, made at Keokuk in the year 1904; the Colby, made in Mason City from 1911-13 by the Colby Manufacturing Co.; the L.C.E., produced by L. C. Erbes during the years 1915-16 at Waterloo and Jackson, Michigan; the Mason Motor Car Company, produced two cars at Waterloo; the Spaulding, produced in Grinnell from 1913-17 (it also was listed twice); and the "Iowa" (no other information given).

The Department of History and Archives is truly grateful to the Maytag Company for donating to the State of Iowa this magnificent product of early car manufacturing in Iowa.

\section{A Short History of The Mental Health Institute at Mount Pleasant 1855-1899}

By Gregory Calvert

Mr. Calvert, a native of Muscatine, Iowa, studied History at Iowa Wesleyan College in Mount Pleasant. While a student there he worked as an aide at the Mental Health Institute and became interested in the history of the hospital. In hearing numerous stories of the Hospital's early days, Mr. Calvert felt there was a need to sort fact from fiction, and when the opportunity arose in the form of a research course, he set about to research and write the following article.

Before a meeting of the Fifth General Assembly of the Iowa State Legislature in 1855, Governor George Grimes proposed that a state institution for the insane be established in southeast Iowa. On January 24, 1855, the General Assembly appropriated $\$ 4,425$ for purchase of an acreage. The law 
Copyright of Annals of Iowa is the property of State of Iowa, by \& through the State Historical Society of Iowa and its content may not be copied or emailed to multiple sites or posted to a listserv without the copyright holder's express written permission. However, users may print, download, or email articles for individual use. 